\title{
INTERNATIONAL \\ Effect of neutralising substances on reducing the influence of cobalt on the content of selected elements in soil
}

\author{
Milena Kosiorek and Mirosław Wyszkowski®* \\ Department of Environmental Chemistry, University of Warmia and Mazury in Olsztyn, 10-727 Olsztyn, plac Łódzki 4, Poland \\ Received March 2, 2018; accepted October 18, 2018
}

\begin{abstract}
The objective of this study was to determine the effect of cobalt on the content of total organic carbon, total nitrogen, the available forms of phosphorus, potassium and magnesium and the $\mathrm{C}: \mathrm{N}$ ratio in soil, following the application of neutralising substances. The effect of cobalt in soil was tested on oats (Avena sativa L.). In order to limit the effect of cobalt, the soil was enriched with neutralising substances, i.e. manure, clay, charcoal, zeolite and calcium oxide. In the series with no neutralising substance, the increasing doses of cobalt only caused an increase in the amount of the available potassium, and the highest Co dose favoured an increase in the organic carbon content and a wider $\mathrm{C}: \mathrm{N}$ ratio in soil. All the substances affected the content of the available potassium in soil, with charcoal, and especially manure, contributing to its elevated accumulation. Besides, manure fostered a growth in the soil content of the available phosphorus, charcoal - the content of organic carbon and the available potassium, and zeolite - the total nitrogen content, while calcium oxide promoted a higher content of total nitrogen and the available phosphorus. Clay and charcoal (unlike zeolite) caused the widening of the $\mathrm{C}: \mathrm{N}$ ratio in soil.
\end{abstract}

Keywords: cobalt contamination, sorbents, soil, elements, $\mathrm{C}: \mathrm{N}$ ratio

\section{INTRODUCTION}

Soil environment is one of the ecosystems which are essential to living organisms (Kabir et al., 2014). Although the soil condition is affected by natural factors, certain anthropogenic factors have also come to play an increasing role (Brio et al., 2013; Liu et al., 2014). The major anthropogenic soil contaminants include trace elements (Adamczyk-Szabela et al., 2017; Garba et al., 2012). The presence of trace elements is largely affected by their min-

*Corresponding author e-mail: miroslaw.wyszkowski@uwm.edu.pl ing, the combustion of different fuels, and industrial and agricultural activities (Adamczyk-Szabela et al., 2017; Brodowska et al., 2016; Zupančič and Skobe, 2014).

Cobalt is one of the many trace metals present in soil. The natural concentration of cobalt does not usually exceed $12 \mathrm{mg} \mathrm{kg}^{-1}$ (Sheppard et al., 2007) but it depends, to the greatest extent, on the bedrock in a specific type of soil (Cappuyns and Mallaerts, 2014). The greatest accumulators of cobalt include igneous rocks, which can accumulate up to $200 \mathrm{mg} \mathrm{kg}^{-1}$ of cobalt. Cobalt also occurs in minerals, such as cobaltite, spherocobaltite and linneite (Luo et al., 2010), which are found in soil. Cobalt is released to the soil solution in erosion processes, during which it is fixed into the mineral and mineral-organic complex. Cobalt occurs in soil as $\mathrm{Co}^{2+}, \mathrm{Co}^{3+}, \mathrm{CoOH}^{+}$and $\mathrm{Co}(\mathrm{OH})_{3}^{-}$(Tappero et al., 2007). The natural concentration of cobalt in soil is exceeded mainly because of human activities and, more specifically, as a result of the combustion of hard coal, automotive fuels and the process of mining cobalt ore for industrial purposes (Mahapatra et al., 2013). Both excessively high and low concentrations of cobalt in soil can seriously disrupt the growth processes in plants, animals and humans (Ballestrazzi et al., 2009). The occurrence of cobalt in such concentrations that are in excess of the acceptable levels also contributes to changing soil properties (Kosiorek and Wyszkowski, 2016a; 2016b; Zaborowska et al., 2016), and proves to have a considerable effect on the concentration of organic carbon and macronutrients (Cappuyns and Mallaerts, 2014; Gad, 2012). Therefore, effective methods of limiting its effect on both soil properties and plants 
should be sought. Phytoremediation can be considered a method of eliminating cobalt from soils (AdamczykSzabela et al., 2017; Alkorta et al., 2004).

Considering all this, a study was conducted to determine the effect of cobalt on the content of organic carbon, total nitrogen and the available forms of phosphorus, potassium and magnesium in soil, as well as the $\mathrm{C}: \mathrm{N}$ ratio in soil, following the application of neutralising substances.

\section{MATERIALS AND METHODS}

An experiment was conducted in the plant growing room of the University of Warmia and Mazury in Olsztyn (northeast of Poland) on acidic soil with the following properties: $\mathrm{pH}$ in $1 \mathrm{M} \mathrm{KCl}-5.05$; hydrolytic acidity (HAC) -28.40 mmol(+) $\mathrm{kg}^{-1}$; total exchangeable cations (TEB) -46.50 mmol(+) $\mathrm{kg}^{-1}$; cation exchange capacity $(\mathrm{CEC})-74.90$ $\operatorname{mmol}(+) \mathrm{kg}^{-1}$; base saturation $(\mathrm{BS})-68.08 \%$, the content of organic carbon $-12.15 \mathrm{~g} \mathrm{~kg}^{-1}$, total nitrogen $-0.73 \mathrm{~g} \mathrm{~kg}^{-1}$, the $\mathrm{C}: \mathrm{N}$ ratio -16.64 , and the content of the available forms of: phosphorus, potassium and magnesium: 40.99, 46.29 , and $116.21 \mathrm{mg} \mathrm{kg}^{-1}$ of soil, respectively. The soil had a textural composition typical of loamy sand (sand $>0.05 \mathrm{~mm}-73.9 \%$, silt $0.002-0.05 \mathrm{~mm}-24.1 \%$ and clay $<0.002 \mathrm{~mm}-2.0 \%$ ). The effect of cobalt at 0,20 , 40, 80, 160 and $320 \mathrm{mg} \mathrm{Co} \mathrm{kg}^{-1}$ of soil was tested on oats (Avena sativa L.), Zuch cultivar (15 plants per pot). Cobalt was applied as cobalt chloride. The cobalt doses in the experiment were chosen in accordance with the Regulation of the Minister of the Environment of 9 September 2002 on soil quality standards and earth quality standards. In order to reduce the effect of cobalt, neutralising substances were applied to soil, i.e. manure (granulated bovine manure), clay, charcoal and zeolite at $2 \%$ of the soil weight, and calcium oxide at a dose corresponding to 1 unit of hydrolytic acidity (HAC). The kinds and doses of sorbents were determined on the basis of their influence on soil physicochemical properties, and especially the reactive and sorption properties of soil. The chemical composition of these additives was as follows: manure: Corg $-149.0 \mathrm{~g} \mathrm{~kg}^{-1}$, total nitrogen $-20.0 \mathrm{~g} \mathrm{~kg}^{-1}$, the $\mathrm{C}: \mathrm{N}$ ratio $-7.45, \mathrm{P}-21.80 \mathrm{~g} \mathrm{~kg}^{-1}$, $\mathrm{K}-16.30 \mathrm{~g} \mathrm{~kg}^{-1}$, and $\mathrm{Mg}-6.020 \mathrm{~g} \mathrm{~kg}^{-1}$; clay: $\mathrm{P}-1.088 \mathrm{~g}$ $\mathrm{kg}^{-1}, \mathrm{~K}-1.290 \mathrm{~g} \mathrm{~kg}^{-1}$, and $\mathrm{Mg}-0.525 \mathrm{~g} \mathrm{~kg}^{-1}$; charcoal: $\mathrm{P}-0.260 \mathrm{~g} \mathrm{~kg}^{-1}, \mathrm{~K}-0.766 \mathrm{~g} \mathrm{~kg}^{-1}$, and $\mathrm{Mg}-0.477 \mathrm{~g} \mathrm{~kg}^{-1}$; zeolite: $\mathrm{P}-1.836 \mathrm{~g} \mathrm{~kg}^{-1}, \mathrm{~K}-5.435 \mathrm{~g} \mathrm{~kg}^{-1}$, and $\mathrm{Mg}-0.553 \mathrm{~g}$ $\mathrm{kg}^{-1}$; as well ascalcium oxide: $\mathrm{P}-0.088 \mathrm{~g} \mathrm{~kg}^{-1}, \mathrm{~K}-0.436 \mathrm{~g}$ $\mathrm{kg}^{-1}$, and $\mathrm{Mg}-0.901 \mathrm{~g} \mathrm{~kg}^{-1}$. The effect of cobalt and these sorbents on both $\mathrm{pH}$ and sorption properties of soil was published in this paper (Kosiorek and Wyszkowski, 2016a). Moreover, the soil was mixed with equal amounts of minerals, corresponding to nutritional demands of plants (100 mg N $-\mathrm{NH}_{4} \mathrm{NO}_{3} ; 35 \mathrm{mg} \mathrm{P}-\mathrm{KH}_{2} \mathrm{PO}_{4} ; 100 \mathrm{mg} \mathrm{K}-$ $\mathrm{KCl} ; 50 \mathrm{mg} \mathrm{Mg}-\mathrm{MgSO}_{4} 7 \mathrm{H}_{2} \mathrm{O} ; 0.33 \mathrm{mg} \mathrm{B}-\mathrm{H}_{3} \mathrm{BO}_{3} ; 5 \mathrm{mg}$ $\mathrm{Mn}-\mathrm{MnCl}_{2} 4 \mathrm{H}_{2} \mathrm{O}$ and $5 \mathrm{mg} \mathrm{Mo} \mathrm{kg}{ }^{-1}$ of soil $-\left(\mathrm{NH}_{4}\right)_{6} \mathrm{Mo}_{7} \mathrm{O}_{24}$ $4 \mathrm{H}_{2} \mathrm{O}$. The soil $(9 \mathrm{~kg})$ was then transferred to polyethylene pots and oats was sown. The moisture content at $60 \%$ of the capillary water capacity was maintained during plant growth. After 78 days from the experiment commencement soil samples for laboratory tests were collected in the period of full oats maturity.

Before the laboratory analyses, the soil was dried and sieved through a $1 \mathrm{~mm}$ mesh sieve. The following parameters were determined in the samples: organic carbon - by the Tiurin method and total nitrogen - by the Kjeldahl method. The concentration of the available forms of phosphorus and potassium was determined by the Egner-Riehm method, and that of the available magnesium $(\mathrm{Mg})$ - by the Schachtschabel method. The results at the end of the experiment were worked out statistically with a two-way analysis of variance ANOVA, the principal component analysis (PCA) and the coefficients of Pearson's linear correlation using the Statistica software package (StatSoft Inc., 2014).

\section{RESULTS AND DISCUSSION}

The laboratory analyses showed that the soil properties under examination depended on its contamination with cobalt and the application of neutralising substances. The contamination of soil with 20,40 and $80 \mathrm{mg} \mathrm{Co} \mathrm{kg}^{-1}$ of soil, in a series with no neutralising substances, only slightly affected the content of organic carbon (Table 1). The greatest increase in its concentration (by 26\%) was observed in the soil contaminated with $320 \mathrm{mg}$ of $\mathrm{Co} \mathrm{kg}^{-1}$. The increasing doses of cobalt did not significantly affect the content of total nitrogen in soil (Table 1). The C:N ratio in the soil contaminated with $320 \mathrm{mg}$ of Co kg-1 was found to widen from 15.19 to 18.70 . The contamination of soil with cobalt did not have any obvious effect on the concentration of the available phosphorus or magnesium in soil (Table 2). After cobalt was added to soil, the content of the available potassium in soil with no additives increased significantly, as compared to the control (by 71\%), when the largest dose of cobalt was added.

Studies by Cappuyns and Mallaerts (2014) also revealed significant correlations between the content of cobalt and the content of organic carbon in soil. The ploughing layer of soil, which contains large amounts of organic carbon, was also found to exhibit high concentrations of cobalt. According to Gad (2012), the appropriate fertilisation of soil with cobalt could increase the content of nitrogen, phosphorus and potassium in soil. Significant relationships between the amounts of $\mathrm{N}_{2}$ reduced by Rhizobium galegae, and the amount of cobalt accumulated both in soil and plants, were demonstrated by Symanowicz and Kalembasa (2012). The appropriate fertilisation with cobalt was proven to have a significantly positive effect on the formation of leghemoglobin, which not only plays a major role in fixing nitrogen, but also significantly improves the activity of root nodules in Fabaceae plants (Awomi et al., 2012). 
Table 1. Effect of cobalt contamination and neutralising substances on content of organic carbon, total nitrogen, and C:N ratio in soil

\begin{tabular}{|c|c|c|c|c|c|c|c|}
\hline \multirow{2}{*}{$\begin{array}{c}\text { Cobalt dose } \\
\left(\mathrm{mg} \mathrm{kg}^{-1} \text { of soil) }\right.\end{array}$} & \multicolumn{7}{|c|}{ Kind of substance neutralising effect of cobalt } \\
\hline & $\begin{array}{l}\text { Without } \\
\text { additions }\end{array}$ & Manure & Clay & Charcoal & Zeolite & $\begin{array}{l}\text { Calcium } \\
\text { oxide }\end{array}$ & $\begin{array}{c}\text { Average } \\
\text { from all series }\end{array}$ \\
\hline \multicolumn{8}{|c|}{$\mathrm{C}_{\text {org. }}\left(\mathrm{g} \mathrm{kg}^{-1}\right)$} \\
\hline 0 & 12.00 & 12.30 & 13.95 & 15.90 & 11.55 & 12.15 & 12.98 \\
\hline 20 & 12.90 & 11.70 & 14.85 & 15.00 & 12.90 & 11.25 & 13.10 \\
\hline 40 & 11.70 & 13.20 & 11.10 & 14.70 & 12.00 & 11.10 & 12.30 \\
\hline 80 & 12.30 & 14.40 & 15.00 & 15.30 & 12.45 & 10.80 & 13.38 \\
\hline 160 & 11.10 & 12.60 & 12.90 & 13.35 & 11.10 & 10.95 & 12.00 \\
\hline 320 & 15.15 & 13.35 & 12.90 & 13.05 & 10.80 & 12.60 & 12.98 \\
\hline Average & 12.53 & 12.93 & 13.45 & 14.55 & 11.80 & 11.48 & 12.79 \\
\hline $\mathrm{r}$ & $0.666^{* *}$ & 0.333 & -0.234 & $-0.884 * *$ & $-0.725 * *$ & 0.463 & -0.102 \\
\hline LSD & \multicolumn{7}{|c|}{$\mathrm{a}-1.24 * *, \mathrm{~b}-1.24 * *, \mathrm{a} b-3.03^{* *}$} \\
\hline \multicolumn{8}{|c|}{ Total-N $\left(\mathrm{g} \mathrm{kg}^{-1}\right)$} \\
\hline 0 & 0.79 & 0.83 & 0.74 & 0.69 & 0.94 & 0.78 & 0.80 \\
\hline 20 & 0.80 & 0.82 & 0.75 & 0.74 & 0.93 & 0.77 & 0.80 \\
\hline 40 & 0.75 & 0.78 & 0.68 & 0.87 & 0.88 & 0.39 & 0.73 \\
\hline 80 & 0.80 & 0.77 & 0.73 & 0.90 & 1.30 & 0.36 & 0.81 \\
\hline 160 & 0.80 & 0.77 & 0.71 & 0.89 & 0.84 & 3.21 & 1.20 \\
\hline 320 & 0.81 & 0.69 & 0.73 & 0.85 & 1.52 & 5.81 & 1.74 \\
\hline Average & 0.79 & 0.78 & 0.72 & 0.82 & 1.07 & 1.89 & 1.01 \\
\hline $\mathrm{r}$ & $0.495^{*}$ & $-0.949 * *$ & -0.044 & $0.487^{*}$ & $0.700 * *$ & $0.955^{* *}$ & $0.974 * *$ \\
\hline LSD & \multicolumn{7}{|c|}{$\mathrm{a}-0.03^{* *}, \mathrm{~b}-0.03^{* *}, \mathrm{a} \mathrm{b}-0.07^{* *}$} \\
\hline \multicolumn{8}{|c|}{$\mathrm{C}: \mathrm{N}$ ratio } \\
\hline 0 & 15.19 & 14.82 & 18.85 & 23.04 & 12.29 & 15.58 & 16.63 \\
\hline 20 & 16.13 & 14.27 & 19.80 & 20.27 & 13.87 & 14.61 & 16.49 \\
\hline 40 & 15.60 & 16.92 & 16.32 & 16.90 & 13.64 & 28.46 & 17.97 \\
\hline 80 & 15.38 & 18.70 & 20.55 & 17.00 & 9.58 & 30.00 & 18.53 \\
\hline 160 & 13.88 & 16.36 & 18.17 & 15.00 & 13.21 & 3.41 & 13.34 \\
\hline 320 & 18.70 & 19.35 & 17.67 & 15.35 & 7.11 & 2.17 & 13.39 \\
\hline Average & 15.81 & 16.74 & 18.56 & 17.93 & 11.62 & 15.70 & 16.06 \\
\hline $\mathrm{r}$ & $0.601 *$ & $0.729 * *$ & -0.277 & $-0.724 * *$ & $-0.752 * *$ & $-0.655^{* *}$ & $-0.751 * *$ \\
\hline LSD & \multicolumn{7}{|c|}{$\mathrm{a}-1.79^{* *}, \mathrm{~b}-1.79^{* *}, \mathrm{a} b-4.39^{* *}$} \\
\hline
\end{tabular}

LSD for: $\mathrm{a}-$ cobalt dose, $\mathrm{b}-$ kind of neutralising substance, $\mathrm{a}, \mathrm{b}-$ interaction. Significant at $* \mathrm{p} \leq 0.05, * * \mathrm{p} \leq 0.01, \mathrm{r}-$ correlation coefficient.

A positive effect of cobalt on the nitrogen content in soil was also found by Boom (2002). These findings partly confirm the experiments mentioned above, because the increasing doses of cobalt in soil only brought about an increase in the content of nitrogen and available potassium.

Among the neutralising substances used in the experiment, charcoal (followed by clay) increased the organic content in soil to the greatest extent (by 16 and 7\%, on average), as compared to the soil with no additives (Table 1). The soil with calcium oxide and zeolite was found to con- tain significantly more nitrogen (139 and 35\%). The greatest widening of the $\mathrm{C}: \mathrm{N}$ ratio in soil was observed in the soil with an addition of clay (from 15.81 to 18.56 ) and charcoal (from 15.81 to 17.93 ) (Table 1). Introducing zeolite to soil lowered the $\mathrm{C}: \mathrm{N}$ ratio to the greatest extent (from 15.81 to 11.62). Except for clay and charcoal, all of the neutralising substances increased the content of the available phosphorus in soil (Table 2). As regards the other substances, their amounts in soil were increased to the greatest extent by manure $(+45 \%)$ and calcium oxide $(+21 \%)$. Manure and 
Table 2. Effect of cobalt contamination and neutralising substances on content of available phosphorus, potassium and magnesium in soil

\begin{tabular}{|c|c|c|c|c|c|c|c|}
\hline \multirow{2}{*}{$\begin{array}{c}\text { Cobalt dose } \\
\left(\mathrm{mg} \mathrm{kg}^{-1} \text { of soil }\right)\end{array}$} & \multicolumn{7}{|c|}{ Kind of substance neutralising effect of cobalt } \\
\hline & $\begin{array}{l}\text { Without } \\
\text { additions }\end{array}$ & Manure & Clay & Charcoal & Zeolite & $\begin{array}{l}\text { Calcium } \\
\text { oxide }\end{array}$ & $\begin{array}{c}\text { Average from all } \\
\text { series }\end{array}$ \\
\hline \multicolumn{8}{|c|}{$\mathrm{P}\left(\mathrm{mg} \mathrm{kg}^{-1}\right)$} \\
\hline 0 & 49.79 & 71.92 & 50.32 & 52.56 & 50.08 & 58.12 & 55.47 \\
\hline 20 & 48.85 & 74.89 & 51.68 & 53.24 & 55.34 & 65.38 & 58.23 \\
\hline 40 & 54.70 & 74.70 & 48.39 & 48.33 & 52.22 & 66.45 & 57.47 \\
\hline 80 & 50.48 & 72.62 & 51.06 & 49.07 & 51.20 & 61.91 & 56.06 \\
\hline 160 & 50.27 & 71.79 & 50.18 & 49.78 & 58.36 & 58.52 & 56.48 \\
\hline 320 & 50.51 & 77.08 & 51.76 & 54.06 & 56.54 & 57.02 & 57.83 \\
\hline Average & 50.77 & 73.83 & 50.57 & 51.17 & 53.96 & 61.23 & 56.92 \\
\hline $\mathrm{r}$ & -0.054 & $0.535^{*}$ & 0.392 & 0.318 & $0.644 * *$ & $-0.598^{*}$ & 0.305 \\
\hline LSD & \multicolumn{7}{|c|}{$\mathrm{a}-1.68 * *, \mathrm{~b}-1.68^{* *}, \mathrm{a} \mathrm{b}-4.12 * *$} \\
\hline \multicolumn{8}{|c|}{$\mathrm{K}\left(\mathrm{mg} \mathrm{kg}^{-1}\right)$} \\
\hline 0 & 49.06 & 197.91 & 51.81 & 65.99 & 31.23 & 44.84 & 73.47 \\
\hline 20 & 54.12 & 173.39 & 51.54 & 72.04 & 36.79 & 44.49 & 72.06 \\
\hline 40 & 54.89 & 195.12 & 58.84 & 80.47 & 32.16 & 42.86 & 77.39 \\
\hline 80 & 55.67 & 201.20 & 56.41 & 80.63 & 33.03 & 43.28 & 78.37 \\
\hline 160 & 92.64 & 204.24 & 67.46 & 87.82 & 37.68 & 52.75 & 90.43 \\
\hline 320 & 83.84 & 197.30 & 70.04 & 91.62 & 49.54 & 63.03 & 92.56 \\
\hline Average & 65.04 & 194.86 & 59.35 & 79.76 & 36.74 & 48.54 & 80.71 \\
\hline $\mathrm{r}$ & $0.822 * *$ & 0.358 & $0.914 * *$ & $0.875 * *$ & $0.924 * *$ & $0.955^{* *}$ & $0.927 * *$ \\
\hline LSD & \multicolumn{7}{|c|}{$\mathrm{a}-3.85^{* *}, \mathrm{~b}-3.85^{* *}, \mathrm{a} b-9.47^{* *}$} \\
\hline \multicolumn{8}{|c|}{$\operatorname{Mg}\left(\mathrm{mg} \mathrm{kg}^{-1}\right)$} \\
\hline 0 & 159.78 & 166.20 & 163.49 & 163.14 & 163.97 & 162.85 & 163.24 \\
\hline 20 & 159.67 & 165.85 & 164.31 & 164.74 & 165.37 & 165.28 & 164.20 \\
\hline 40 & 160.03 & 167.49 & 164.89 & 163.60 & 165.04 & 163.04 & 164.02 \\
\hline 80 & 159.92 & 167.49 & 166.73 & 164.16 & 166.27 & 163.13 & 164.62 \\
\hline 160 & 162.54 & 168.75 & 165.22 & 162.85 & 163.93 & 162.72 & 164.34 \\
\hline 320 & 159.17 & 168.48 & 164.11 & 165.18 & 167.45 & 164.31 & 164.78 \\
\hline Average & 160.19 & 167.38 & 164.79 & 163.95 & 165.34 & 163.56 & 164.20 \\
\hline $\mathrm{r}$ & 0.020 & $0.790 * *$ & 0.000 & 0.436 & $0.627 * *$ & 0.144 & $0.716^{* *}$ \\
\hline LSD & \multicolumn{7}{|c|}{$\mathrm{a}-1.08^{* *}, \mathrm{~b}-1.08^{* *}, \mathrm{a} \mathrm{b}-2.64^{* *}$} \\
\hline
\end{tabular}

LSD for: $\mathrm{a}-$ cobalt dose, $\mathrm{b}-$ kind of neutralising substance; $\mathrm{a} \mathrm{b}-$ interaction, significant at $* \mathrm{p} \leq 0.05, * * \mathrm{p} \leq 0.01, \mathrm{r}-$ correlation coefficient.

charcoal significantly increased the content of the available potassium in soil (by 200 and $23 \%$, on average), whereas the application of zeolite, calcium oxide and clay resulted in its decrease (by 44, 25 and 9\%). All of the neutralising substances had a slightly positive effect on the concentration of the available magnesium in soil (Table 2).

The correlation coefficients calculated for this study have shown that the most significant $(\mathrm{p} \leq 0.01)$ negative correlations exist between the content of organic carbon and both $\mathrm{pH}$ and total nitrogen, as well as between total nitro- gen and both hydrolytic acidity and the $\mathrm{C}: \mathrm{N}$ ratio. Positive correlations were found to exist between the content of the available phosphorus and $\mathrm{pH}$, the available potassium and magnesium, as well as between the available potassium and magnesium, and between the content of organic carbon and the $\mathrm{C}: \mathrm{N}$ ratio in soil (Table 3 ).

The significance of the correlations for $p \leq 0.05$ has been demonstrated in several other cases. Figure 1 shows the content of organic carbon, total nitrogen, phosphorus, potassium and magnesium, and the $\mathrm{C}: \mathrm{N}$ ratio in soil as 
Table 3. Correlation coefficients (r) between content of elements and C:N ratio and some properties of soil

\begin{tabular}{ccccccc}
\hline Variable & $\mathrm{C}_{\text {org }}$ & Total-N & $\mathrm{C}: \mathrm{N}$ ratio & $\mathrm{P}$ & $\mathrm{K}$ & $\mathrm{Mg}$ \\
\hline $\mathrm{pH}$ & $-0.383^{* *}$ & $0.563^{* *}$ & $-0.553^{* *}$ & $0.353^{* *}$ & -0.213 & 0.054 \\
HAC & 0.216 & $-0.408^{* *}$ & $0.352^{* *}$ & $-0.298^{*}$ & $0.245^{*}$ & -0.072 \\
TEB & -0.164 & $0.244^{*}$ & -0.184 & $0.266^{*}$ & -0.177 & -0.133 \\
CEC & -0.135 & 0.176 & -0.120 & $0.234^{*}$ & -0.142 & -0.139 \\
BS & -0.168 & 0.176 & -0.148 & $0.293^{*}$ & -0.150 & -0.102 \\
C & & $-0.371^{*}$ & $0.765^{* *}$ & -0.152 & 0.124 & 0.001 \\
Total-N & & & $-0.853^{* *}$ & 0.012 & $-0.277^{*}$ & 0.105 \\
C:N ratio & & & -0.060 & $0.232^{*}$ & -0.031 \\
P & & & & $0.760^{* *}$ & $0.554^{* *}$ \\
K & & & & & $0.509^{* *}$ \\
\hline
\end{tabular}

$\mathrm{pH}_{\mathrm{KCl}}-\mathrm{pH}$ in $1 \mathrm{M} \mathrm{KCl}, \mathrm{HAC}$ - hydrolytic acidity, TEB - total exchangeable bases, CEC - cation exchange capacity, BS - base saturation. Significant at $* \mathrm{p} \leq 0.05, * * \mathrm{p} \leq 0.01, \mathrm{r}-$ correlation coefficient.

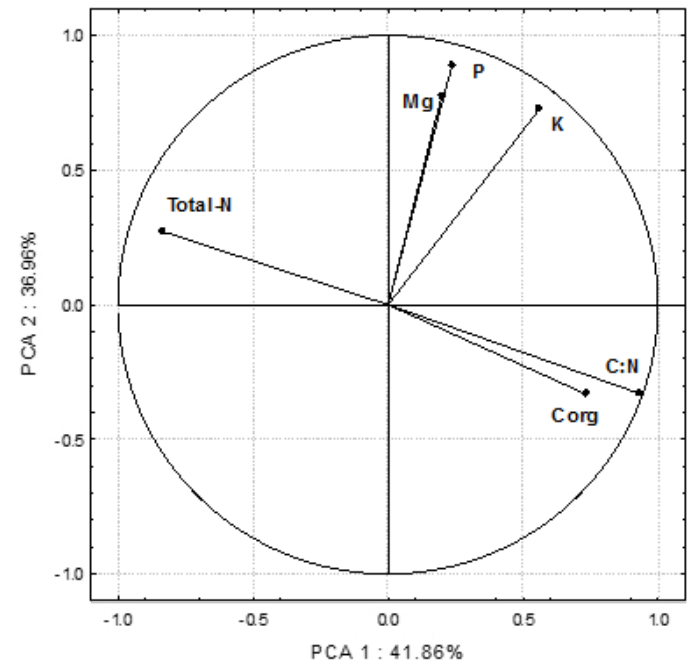

Fig. 1. Content of organic carbon, total nitrogen, phosphorus, potassium and magnesium and $\mathrm{C}: \mathrm{N}$ ratio in the soil illustrated with the PCA method. Key: vectors represent analyzed variable (content of $\mathrm{C}_{\text {org }}$, total-N, available $\mathrm{P}, \mathrm{K}, \mathrm{Mg}$ and $\mathrm{C}: \mathrm{N}$ ratio).

vector variables affected by cobalt and neutralising substances (manure, clay, charcoal, zeolite and calcium oxide). The value of vectors denoting the available phosphorus, magnesium and potassium in soil was nearly $37 \%$ of the total correlation of the data set; furthermore, the value of total nitrogen, organic carbon and the $\mathrm{C}: \mathrm{N}$ ratio in soil was nearly $42 \%$. The vector which illustrates the content of magnesium and organic carbon was shorter than the other vectors, so it can be concluded that they contributed little to the variability studied. The PCA illustrates a highly significant correlation between the vectors denoting the available phosphorus and magnesium, as well as organic carbon and the C:N ratio in soil (Fig. 1). A significant (but much weaker) correlation was observed between the available phosphorus and magnesium, and the available potassium. However, a negative correlation was observed between total nitrogen and organic carbon, and the $\mathrm{C}: \mathrm{N}$ ratio. No

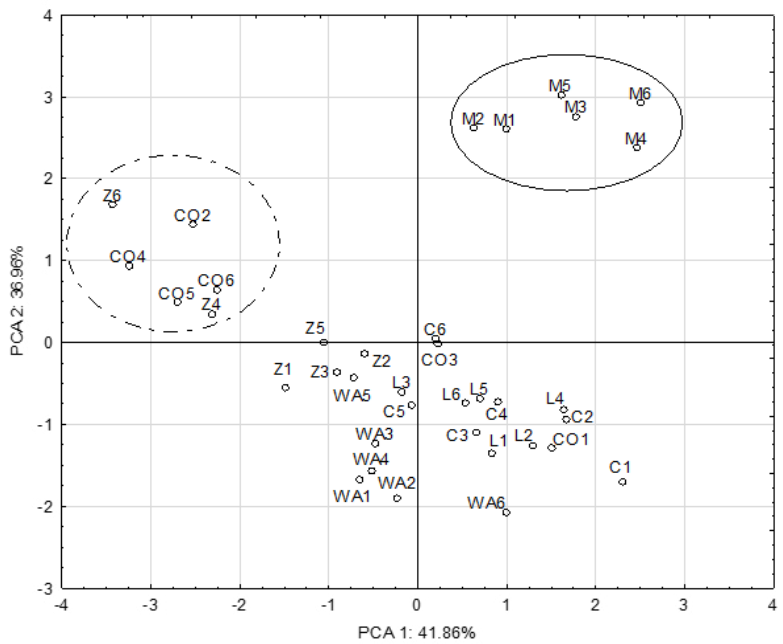

Fig. 2. Effect of neutralising substances on content of macroelements and $\mathrm{C}: \mathrm{N}$ ratio in the soils illustrated with the PCA method. Key: points show soil samples with elements and $\mathrm{C}: \mathrm{N}$ ratio (WA without additions, $\mathrm{M}$ - manure, $\mathrm{L}$ - clay, $\mathrm{C}$ - charcoal, $\mathrm{Z}$ - zeolite, $\mathrm{CO}$ - calcium oxide, $1-0 \mathrm{mg}, 2-20 \mathrm{mg}, 3-40 \mathrm{mg}, 4-80 \mathrm{mg}$, $5-160 \mathrm{mg}, 6-320 \mathrm{mg} \mathrm{Co} \mathrm{kg}{ }^{-1}$ of soil).

significant correlations were observed between the other variables. The dispersion of the PCA results (Fig. 2) shows that an addition of manure, followed by calcium oxide, had the greatest effect on the soil properties under examination (especially on the content of phosphorus, potassium and magnesium).

A beneficial effect of adding substances with a high content of organic matter on the amount of organic carbon in soil was observed in a study by Aoyama and Kumakura (2001). The application of elements with organic substances caused an increase in these elements in soil. The content of organic carbon may be positively correlated with hydrolytic acidity (Šimanský and Kováčik, 2015). Beak et al. (2011) reported that the cobalt ions present in the soil solution showed a high affinity to organic ligands. If their content was too low, cobalt was fixed on the mineral surface, mainly to iron and manganese oxides. It was found in an earlier study by Kosiorek and Wyszkowski (2016a) that the 
soil $\mathrm{pH}$ increased after calcium oxide, zeolite and manure were added to it. An increase in the soil $\mathrm{pH}$ promotes the immobilisation of cobalt in a soil solution, thereby reducing its toxicity to plants (Lago-Vila et al., 2015; Li et al., 2009; Wendling et al., 2009). A significant effect of $\mathrm{pH}$ and $\mathrm{CaCO}_{3}$ on the content of cobalt in soil was suggested by Kabir et al. (2014).

According to Boom (2002), maintaining the soil $\mathrm{pH}$ between 6 and 6.5, along with the appropriate content of cobalt in soil (among other things), has a significant effect on the activity of soil organisms and, in consequence, on the fixation of nitrogen. Since it brings about a change in the soil $\mathrm{pH}$ (a decrease in its acidity), the application of calcium oxide to soil can increase the content of the available potassium and magnesium (Wyszkowski and Sivitskaya, 2012). These factors also have an effect on the C:N ratio in soil. A narrower $\mathrm{C}: \mathrm{N}$ ratio is correlated with a more intensive mineralisation process which, in turn, favours the release of macronutrients essential for plant growth (Fanin et al., 2013; Heuck et al., 2015). A decrease in the C:N ratio has a positive effect on the nitrogen content in soil because the uptake of this and other elements by plants from the soil solution was smaller. These relations were observed in our study. According to a study conducted by Tsai et al. (2012), the application of a substance containing a large percentage of organic matter, such as manure, increases the content of macronutrients in soil. The application of manure to soil caused in an increase in the content of total nitrogen (Temmerman et al., 2003, Delgado and Follett, 2002) phosphorus and potassium in soil (Delgado and Follett, 2002). According to Wright et al. (2007), compost increased the contents of the available phosphorus, potassium and magnesium in soil. In a study conducted by Wyszkowski and Sivitskaya (2012), zeolite increased the content of the available magnesium in soil, whereas Wyszkowski and Modrzewska (2016) found the use of zeolite to have a positive effect on the content of organic carbon, the available phosphorus and the $\mathrm{C}: \mathrm{N}$ ratio in soil. Zeolite increased the content of organic carbon and the available magnesium, in reverse to the phosphorus content in soil (Wyszkowski and Radziemska, 2012). Calcium oxide can also reduce the content of the available phosphorus and organic carbon in soil (Wyszkowski and Sivitskaya, 2012).

\section{CONCLUSIONS}

1. The experiment showed that applying both the increasing doses of cobalt and some neutralising substances to the soil had a significant effect on the content of organic carbon, total nitrogen and the available phosphorus and potassium in the soil.

2. In the soil with no addition of the neutralising substances, a significant increase in the content of organic carbon and a widening of the $\mathrm{C}: \mathrm{N}$ ratio in soil were observed in the soil contaminated with the largest amounts of cobalt. Doses of 160 and $320 \mathrm{mg} \mathrm{Co} \mathrm{kg}^{-1}$ increased the content of the available potassium in soil to the greatest extent. The increasing doses of cobalt did not significantly affect the content of total nitrogen, the available phosphorus or magnesium in soil.

3. Among the neutralising substances used in the experiment, charcoal increased the organic content in soil to the greatest extent; a similar effect was observed for calcium oxide on total nitrogen and for clay - on widening the C:N ratio in soil. The largest increase in the content of the available phosphorus and potassium was observed in soil with manure. A significant decrease in the content of organic carbon and the available potassium in soil was observed in the soil with an addition of zeolite and calcium oxide.

Conflict of interest: The Authors do not declare any conflict of interest.

\section{REFERENCES}

Adamczyk-Szabela D., Romanowska-Duda Z., Lisowska K., and Wolf W.M., 2017. Heavy metal uptake by herbs. V. Metal accumulation and physiological effects induced by thiuram in Ocimum basilicum L. Water Air Soil Pollut., 228, 334. https://doi.org/10.1007/s11270-017-3508-0

Alkorta I., Hernández-Allica J., Becerril J., Amezaga I., Albizu I., and Garbisu C., 2004. Recent findings on the phytoremediation of soils contaminated with environmentally toxic heavy metals and metalloids such as zinc, cadmium, lead, and arsenic. Rev. Environ. Sci. Biotechnol., 3, 71-90. https://doi.org/10.1023/B:RESB.0000040059. $70899.3 \mathrm{~d}$

Aoyama M., and Kumakura N., 2001. Quantitive and qualitative changes of organic matter in an Ando soil induced by mineral fertilizer and cattle manure applications for 20 years. J. Soil Sci. Plant Nut., 47(2), 241-252.

Awomi T. A., Singh A.K., Kumar M., and Bordoloi L.J., 2012. Effect of phosphorus, molybdenum and cobalt nutrition on yield and quality of mungbean (Vigna radiata L.) in acidic soil of Northeast India. Indian J. Hill Farm., 25(2), 22-26.

Balestrazzi A., Bonadei M., Quattrini E., and Carbonera D., 2009. Occurrence of multiple metal-resistance in bacterial isolates with transgenic white poplars (Populus alba L.). Ann. Microbiol., 59, 1-8. https://doi.org/10.1007/BF03175593

Beak D.G., Kirby J.K., Hettiarachachi G.M., Wendling L.A., McLaughlin M.J., and Khatiwada R., 2011. Cobalt distribution and speciation: effect of aging, intermittent submergence, in situ rice roots. J. Environ. Qual., 40(3), 679-695. https://doi.org/10.2134/jeq2010.0139

Boom R., 2002. Healthy soil, healthy grass, healthy stock - the balanced approach. Proc. 1st Virtual Global Conf. Organic Beef Cattle Production, September 2 to October 15, Concordia, Brazil.

Biro K., Pradhan B., Buchroithner M., and Makeschin F., 2013. Land use/land cover change analysis an its impact on soil properties in the Northern part of Gadarif region, Sudan. Land Degrad. Dev., 24, 90-102. https://doi. org/10.1002/1dr.1116 
Brodowska M.S., Kurzyna-Szklarek M., and Haliniarz M., 2016. Selenium in the environment. J. Elem., 21(4), 1173-1185. https://doi.org/10.5601/jelem.2016.21.2.1148

Cappuyns V., and Mallaerts T., 2014. Background values of cobalt in Flemish and European soils. Geol. Belg., 17(2), $107-114$

Delgado J.A., and Follett R.F., 2002. Carbon and nutrient cycles. J. Soil Water Conserv., 57, 6, 455-464.

Fanin N., Fromin N., Buatois B., and Hättenschwiler S., 2013. An experimental test of the hypothesis of non-homeostatic consumer stoichiometry in a plant litter microbe system. Ecol. Lett., 16(6), 764-772. https://doi.org/10.1111/ele.12108

Gad N., 2012. Role and importance of cobalt nutrition on groundnut (Arachis hypogaea) production. World Appl. Sci. J., 20(3), 359-367.

Garba S.T., Osemeahon A.S., Maina H.M., and Barminas J.T., 2012. Ethylenediaminetetraacetate (EDTA)-Assisted phytoremediation of heavy metal contaminated soil by Eleusine indica L. Gearth. J. Environ. Chem. Ecotoxicol., 4(5), 103-109.

Heuck C., Weig A., and Spohn M., 2015. Soil microbial biomass $\mathrm{C}: \mathrm{N}: \mathrm{P}$ stoichiometry and microbial use of organic phosphorus. Soil Biol. Biochem., 85, 119-129. https://doi. org/10.1016/j.soilbio.2015.02.029

Kabir D., Katkar R.N., and Lakhe S.R., 2014. Georeferenced status of cobalt in soils of yavatmal district of Maharashtra. IOSR J. Agric. Vet. Sci. (IOSR-JAVS), 7(2), 10-13.

Kosiorek M., and Wyszkowski M., 2016a. Selected properties of cobalt-contaminated soil following the application of neutralising substances. Environ. Prot. Natural Res., 27(1), 22-25. https://doi.org/10.1515/oszn-2016-0006

Kosiorek M., and Wyszkowski M., 2016b. Effect of neutralising substances on selected properties of soil contaminated with cobalt. J. Ecol. Eng., 17(3), 193-197. https://doi.org/10. 12911/22998993/63337

Lago-Vila M., Arenas-Lago D., Rodríguez-Seijo A., Andrade Couce M.L., and Vega F.A., 2015. Cobalt, chromium and nickel contents in soils and plants from a serpentinite quarry. Solid Earth, 6(1), 323-335. https://doi.org/10.5194/ se-6-323-2015

Li H.F., Gray C., Mico C., Zhao F.J., and McGrath S.P., 2009. Phytotoxicity and bioavailability of cobalt to plants in a range of soils. Chemosphere, 75(7), 979-986. https://doi. org/10.1016/j.chemosphere.2008.12.068

Liu Y., Su C., Zhang H., Li X., and Pei J., 2014. Interaction of soil heavy metal pollution with industrialisation and the landscape pattern in Taiyuan city, China. PloS One, 9(9), 1-14. https://doi.org/10.1371/journal.pone.0105798

Luo D., Zheng H., Chen Y., Wang G., and Fenghua D., 2010. Transfer characteristics of cobalt from soil to crops in the suburban areas of Fujian Province, southeast China. J. Environ. Manag., 91(11), 2248-2253. https://doi.org/10. 016/j.jenvman.2010.06.001

Mahapatra P.S., Ray S., Das N., Mohanty A., Ramulu T.S., Das T., Chaudhury G.R., and Das S.N., 2013. Urban airquality assessment and source apportionment studies for Bhubaneshwar, Odisha. Theor. Appl. Climatol., 112(1), 243-251. https://doi.org/10.1007/s00704-012-0732-9

Sheppard P.R., Speakman R.J., Ridenour G., Glascock M.D., Farris C., and Witten M.L., 2007. Spatial patterns of tungsten and cobalt in surface dust of Fallon, Nevada. Environ. Geochem. Hlth., 29(5), 405-412. https://doi. org/10.1007/s10653-007-9085-1

Šimanský V., and Kováčik P., 2015. Long-term effects of tillage and fertilization on $\mathrm{pH}$ and sorption parameters of haplic Luvisol. J. Elem., 20(4), 1033-1040. https://doi.org/10. 5601/jelem.2015.20.1.857

StatSoft, Inc., 2014. STATISTICA data analysis software system, version 12. www.statsoft.com.

Symanowicz B., and Kalembasa S., 2012. Effect of iron, molybdenum and cobalt on the amount of nitrogen biologically reduced by Rhizobium galegae. Ecol. Chem. Eng., A, 19(11), 1311-1320.

Temmerman L., Vanongeval L., Boon W., Hoenig M., and Geypens M., 2003. Heavy metal content of arable soils in northern Belgium. Water Air Soil Poll., 148, 61-76. https:// doi.org/10.1023/A:1025498629671

Tappero R., Peltier E., Gräfe M., Heidel K., Ginder-Vogel M., Livi K.J., Rivers M.L., Marcus M.A., Chaney R.L., and Sparks D.L., 2007. Hyperaccumulator Alyssum murale relies on a different metal storage mechanism for cobalt than for nickel. New Phytol., 175(4): 641-654. https://doi. org/10.1111/j.1469-8137.2007.02134.x

Tsai W.T., Liu S.C., Chen H.R., Chang Y.M., and Tsai Y.L., 2012. Textural and chemical properties of swine-manurederived biochar pertinent to its potential use as a soil amendment. Chemosphere, 89(2), 198-203. https://doi. org/10.1016/j.chemosphere.2012.05.085

Wendling L.A., Kirby J.K., and McLaughlin M.J., 2009. Aging effects on cobalt availability in soils. Environ. Toxicol. Chem., 28(8), 1609-1617. https://doi.org/10.1897/ 08-544.1

Wright A.L., Provin T.L., Hons F.M., Zuberer D.A., and White R.H., 2007. Compost Skurce and rate effects on soil macronutrient availability under Saint Augustine Grass and Bermuda Grass Turf. Compost Sci. Utiliz., 15, 1, 22-28. https://doi.org/10.1080/1065657X.2007.10702306

Wyszkowski M., and Modrzewska B., 2016. Development of the selected properties of zinc-contaminated soil following an addition of neutralising substances. Polish J. Soil Sci., 49(2), 101-109.

Wyszkowski M., and Radziemska M., 2012. Effect of some substances on the content of organic carbon and mineral components in soils contaminated with chromium. Ecol. Chem. Eng., A, 19, 4-5, 361-368.

Wyszkowski M., and Sivitskaya V., 2012. Changes in the content of organic carbon and available forms of macronutrients in soil under the influence of soil contamination with fuel oil and application of different substances. J. Elem., 17(1), 139-148. https://doi.org/10.5601/jelem.2012.17.1.12

Zaborowska M., Kucharski J., and Wyszkowska J., 2016. Biological activity of soil contaminated with cobalt, tin and molybdenum. Environ. Monit. Assess., 188(7), 398, 1-10.

Zupančič N., and Skobe S., 2014. Antropogenic environment al impact in the Mediterranean coastal area of Koper/ Capodistria, Slovenia. J. Soils Sediment., 14(1), 67-77. https://doi.org/10.1007/s11368-013-0770-7 